This PDF is a selection from an out-of-print volume from the National Bureau of Economic Research

Volume Title: The Rate and Direction of Inventive Activity: Economic and Social Factors

Volume Author/Editor: Universities-National Bureau Committee for Economic Research, Committee on Economic Growth of the Social Science Research Council

Volume Publisher: Princeton University Press

Volume ISBN: 0-87014-304-2

Volume URL: http://www.nber.org/books/univ62-1

Publication Date: 1962

Chapter Title: Inventions in the Postwar American Aluminum Industry Chapter Author: Merton Peck

Chapter URL: http://www.nber.org/chapters/c2123

Chapter pages in book: (p. 279 - 298) 


\title{
Inventions in the Postwar American Aluminum Industry
}

\author{
MERTON J. PECK
}

\section{HARVARD UNIVERSITY}

Aluminum is a striking example of an industry created by invention. Arthur Hall's discovery of the electrolytic process in 1889 provided a commercially feasible method of reducing aluminum, and the growth of aluminum consumption until it is now second only to steel owes much to subsequent inventions. ${ }^{1}$ Inventions in the aluminum industry can be divided into two categories: first, new alloys, new processes in manufacturing products from aluminum, and new techniques for fabricating aluminum ingot that have permitted new commercial uses for aluminum; and, second, new techniques that have reduced the cost of aluminum ingot.

This distinction is based upon the roster of potential inventors. With the first group of inventions, the firms that could both profit from and have the technical knowledge for inventions include the independent fabricators, the manufacturers of end-products made from aluminum, and the makers of fabricating and manufacturing equipment as well as the producers of aluminum ingot. These different types of firms realize the profits from invention in varying ways, so that comparing the nature of the profits of invention for each class of firms with the actual record of invention tests the effects of various incentives and opportunities for invention. With the second group of inventions, the primary aluminum producers are the sole likely source of invention, for these firms alone have access to the technology and can profit directly from introducing inventions into their own operations.

Anti-trust action has transformed the structure of the industry from that of a single domestic seller.of aluminum ingot to a three-firm and later a five-firm oligopoly. ${ }^{2}$ Consequently, the second question for

Note: This paper is drawn from a book-length study, Competition in the American Aluminum Industry, 1945-1955, Cambridge, Mass., 1961.

${ }^{1}$ For the early history of inventions in the aluminum industry, see Donald Wallace, Market Control in the Aluminum Industry, Cambridge, Mass., 1937, App. A.

${ }^{2}$ By volume, aluminum is second only to steel and by tonnage it ranks after steel, copper, lead, and zinc. Since aluminum has a low density, weight comparisons understate its relative importance. See Aluminum, The Industry and the Four North American Producers, New York, 1951, p. 8. 
research is the effects of the change in market structure upon inventive activity for both classes of invention. Finally, even though the inventions here are grouped in terms of several distinct technical problems, these problems encompass most of the recent technical progress in the aluminum industry. What follows then comprises a history of inventions in the aluminum industry from 1946 to $1957 .^{3}$

\section{Sources of the Data}

Invention is defined here as the introduction of a new product or production technique. The standard for novelty is low. It suffices if an invention is described as an advance in the state of the art in either the trade paper of the industry, Modern Metals, or another trade publication. ${ }^{4}$ Such sources may be influenced by the public relations and advertising efforts of the inventor as well as by editorial judgments of readership interest. These sources, however, do impose the minimum level of significance as viewed by the trade press editors.

The inventions so recorded will vary widely in terms of their novelty and economic significance. An attempt has been made to distinguish between major and minor inventions upon the basis of the discussion in the trade press. Evaluating inventions, however, is a difficult problem even for those with more technical qualifications and with more reliable sources than the author's. What is reported here is the discussion in the trade press rather than an ex post analysis of the economic significance of various inventions.

Even though Modern Metals and other trade publications have an impressive record of accuracy and coverage, the preceding discussion indicates the limitations of these sources. The records and calculations of the individual firms were unavailable, a condition which further restricts the reliability of this study and makes the discussion unduly speculative. Therefore, the conclusions should be regarded as tentative, though perhaps no more so than is the case with other histories of invention.

\section{Hypotheses as to the Origin of Inventions}

The aluminum industry is usually considered to be synonomous with the primary aluminum producers : Kaiser, Reynolds, Alcoa, and since 1955, Harvey, Ormet and Anaconda. These firms mine bauxite, pro-

${ }^{3}$ For a discussion of this period, see Harold Stein, "The Disposal of Aluminum Plants," in Public Administration and Policy Development, Harold Stein, editor, New. York, 1952.

- Modern Metals. Another standard source is the Bureau of Mines, Minerals Yearbook. 
cess the bauxite into alumina, and reduce the alumina into aluminum pig and ingot. Approximately three-quarters of the pig and ingot is fabricated in the vertically integrated facilities of the primary producers. ${ }^{5}$ Aluminum fabrications are sold to manufacturers for the production of a wide variety of end products, from aircraft and automobile components to building materials and pots and pans.

The increased consumption of aluminum over the last decades is in part dependent upon advances in the manufacturing techniques for aluminum as well as upon inventions in the aluminum industry narrowly defined. This is particularly so because aluminum is less workable by established production methods than steel or copper. Although these inventions might be considered outside the boundaries of the aluminum industry, the primary aluminum producers obviously profit from advances in the state of the manufacturing art that expand their $\$ 1 \frac{1}{2}$ billion market for aluminum.

Indeed, this situation is highly conducive to invention by firms beyond the narrow limits of the industry. The three primary producers manufacture end-products so that they have direct experience with the technical problems involved. ${ }^{6}$ Their sales engineers are in continuing contact with the end-product manufacturers so that the primary producers can facilitate the adoption of inventions in manufacturing processes. Kaiser, Reynolds, and Alcoa are among the 100 largest American manufacturing companies in the Fortune list. ${ }^{7}$ All three have the extensive research organization of a large corporation. ${ }^{8}$ Primary aluminum reduction is one of the most concentrated of American industries. Hence, if, as is sometimes argued, size and fewness are conducive to invention, the primary producers might well be the major contributors to the technical progress of their customers.

In contrast, the manufacturing processes for aluminum are only one of many technical problems confronting the end-product manufacturer. An end-product manufacturer would profit directly only from

\footnotetext{
${ }^{5}$ See data in Small Business and the Aluminum Industry, A Report of Sub-committee No. 3 to the Select Committee on Small Business, House of Representatives, 84th Cong., 2nd sess., H.R. 2954, 1956, p. 20. Hereafter this document will be cited as Small Business and the Aluminum Industry.

${ }^{6}$ For a description of the range of end-products manufactured by the primary producers see Record, United States vs Aluminum Company of America, S.D.N.Y., 1949, p. 1,791 (Hereafter cited as Remedy Record). Only about 10 to 15 per cent of aluminum ingot output is used by the primary producers in their own end-products.

${ }^{3}$ Alcoa was forty-third, Reynolds eighty-fifth and Kaiser one-hundredth in 1956. Fortune, July 1958, pp. 131-150.

${ }^{8}$ The research organizations as described in various articles in the trade press appear to have the character and size typical of a large manufacturer of producers' durables.
} 
the incorporation of an invention in his own aluminum manufacturing process. Such profits would be relatively modest compared to the gains accruing to a primary producer from an invention resulting in even a small increase in the consumption of aluminum. Yet the endproduct manufacturers, numbering over 24,000 , have the law of large numbers in their favor. ${ }^{9}$ Given the accidental character of invention, this factor might offset the differences in expected profits so that the end-product manufacturers would be a major source of inventions.

Aircraft manufacturers are a special category among the endproduct manufacturers. The manufacturing techniques for aluminum represent an important technical problem for such firms. Furthermore, these firms have large engineering staffs and can charge a share of their research expenses to defense contracts.

Inventions in manufacturing techniques are often incorporated in new machinery so that the makers of equipment for aluminum manufacturing constitute a third source of inventions. An equipment maker profits from these inventions, both through a larger share of the equipment market and an expansion of the total sales of equipment that accompanies an acceleration in the rate of obsolescence of existing machinery and the increased use of aluminum. Compared to the endproduct manufacturers who can utilize a new manufacturing technique directly only in their own operation, the equipment makers can capitalize upon the adoption of an invention by end-product manufacturers generally. This is offset by the smaller size of equipment makers relative to such end-product manufacturers as the aircraft companies, and their smaller number (several hundred firms compared to 24,000 end-product manufacturers).

The comparison of the probable expected profits from invention for the equipment makers and for the primary producers is even more difficult and nebulous. In general, the total profits from the sum of advances in manufacturing techniques are much greater for the primary producers than for the equipment makers simply because the sales of aluminum are so much greater than the sales of equipment. Yet the profits of invention for the equipment makers are more certain, immediate, and greater in proportion to the size of the firm. The equipment makers' profits are more certain since some inventions displace existing machinery rather than facilitate new applications for aluminum. The effects of invention cannot be foreseen with sufficient accuracy to enable the primary producers to discriminate accord-

\footnotetext{
${ }^{\bullet}$ Small Business and the Aluminum Industry, p. 7.
} 
ing to the results of invention, whereas the equipment maker benefits in either case. The equipment makers' profits are more immediate, because the sale of new machinery takes place over a relatively short time, whereas the increase in aluminum consumption from a new use made possible by the machinery occurs over a long time span. Finally, a single invention may change markedly an equipment maker's market share and so create a large percentage change in the firm's profits. Since aluminum has a wide variety of uses, any one invention is unlikely to increase markedly the profits of the primary producers.

In addition, the equipment makers are under more competitive pressures to invent. Relative technical merits are an important element in the sale of equipment so that a firm that does not invent may suffer a loss of market share. Since a loss of market share is said to be a greater stimulus to business effort than an equivalent gain, the existence of these competitive pressures would further favor the equipment makers as a source of inventions. In contrast, an increase in the demand for aluminum from an improvement in manufacturing techniques might be distributed among all the primary producers.

Up to this point only the profits directly realizable from the inventing firm's own operation have been considered. Clearly an endproduct manufacturer could sell patent rights for a new machine to an equipment manufacturer and such transferability makes the economic position of the inventor less decisive. It is assumed here, however, that the market for inventions is sufficiently imperfect so that the sale of inventions does not alter substantially the relative profitability of invention for these three groups. This assumption is further strengthened by the nonpatentability of a minority of these inventions.

These views on the marketability of inventions imply that individual inventors and commercial research organizations will be a relatively minor source of inventions, since their profits from inventions are realized solely through the sale of patent rights. Universities, government laboratories, and foreign sources are considered as sources of invention outside the scope of market incentives and pressures.

Two other types of firms are a priori possible but unlikely sources of inventions in manufacturing techniques. Secondary aluminum producers make aluminum ingot from scrap and sell their ingot in competition with the primary producers. About 100 secondary smelters account for one-fifth of the total domestic aluminum output. ${ }^{10}$ Inde-

${ }^{10}$ Ibid., p. 19. 
pendent fabricators buy ingot from the primary and secondary producers for fabrication and sale to end-product manufacturers. These firms account in total for only a quarter of the fabricating output. ${ }^{11}$ Since both types of firms are individually small compared to the primary producers, they neither realize the profits accruing to primary producers from an increased demand for aluminum nor possess the research funds of a large corporation. Thus, they are likely to be a relatively minor source of inventions.

From this analysis of the nature of the expected profits from invention and the resources for research of the primary producers, the end-product manufacturers, and the equipment makers, it is possible to argue a priori that each will be the major source of inventions. Admittedly, this is a highly qualitative argument based upon the nature of expected profits rather than a quantitative examination of the net historical profits from past inventions for each group. Data is lacking for such a study.

\section{Inventions in Four Technical Areas of the Industry}

\section{JOINING}

To discover which of the three groups - the primary producers, the end-product manufacturers, or the equipment makers-is the major source of inventions in manufacturing techniques for aluminum requires the selection of a technical area that is important for an increase in the total demand for aluminum, of significance to a wide class of end-product manufacturers and with a substantial group of equipment makers. The joining of aluminum fulfills these specifications.

Not only is joining metal components common to the manufacturing of most end-products, but aluminum cannot be joined by conventional welding as easily as other metals. ${ }^{12}$ Joining is a widespread technical problem among the end-product manufacturers, and so it is not surprising that the trade paper Modern Metals states, "It is pretty well known that the principal deterrent to the more extensive use of aluminum is the difficulty in joining." ${ }^{13}$ Finally, there is a well established group of manufacturers of welding equipment for use with

11 lbid., p. 20.

${ }^{12}$ Aluminum has a much lower melting temperature than steel. A tendency for oxidation and the diffusion of heat throughout the metal creates heat reactions. For a discussion see Reynolds Metals Company, Reynolds Aluminum Alloys and Mill Products, Louisville, 1948, p. 18.

${ }^{19}$ Modern Metals, April 1953, p. 46. 
TABLE 1

SOURCes of INVENTIONS IN Four TeChNical AREas of

THE Aluminum IndUSTRY, 1946-57

\begin{tabular}{|c|c|c|c|c|}
\hline \multirow[b]{2}{*}{ Source } & \multirow[b]{2}{*}{ Joining } & \multicolumn{2}{|c|}{ Technical Area } & \multirow[b]{2}{*}{ Alloys } \\
\hline & & Finishing & Fabricating & \\
\hline & (1) & (2) & (3) & (4) \\
\hline Primary aluminum producers & 6 & 1 & 10 & $30^{a}$ \\
\hline Independent fabricators & 0 & $\mathbf{0}$ & 13 & 2 \\
\hline Secondary aluminum producers & 1 & 0 & 0 & 1 \\
\hline $\begin{array}{l}\text { End-product manufacturers } \\
\text { Aircraft } \\
\text { Other }\end{array}$ & $\begin{array}{l}6 \\
3\end{array}$ & $\begin{array}{l}7 \\
2\end{array}$ & $\begin{array}{l}5 \\
1\end{array}$ & 1 \\
\hline Equipment manufacturers & 26 & 13 & 37 & 0 \\
\hline $\begin{array}{l}\text { Commercial research and } \\
\text { development companies }\end{array}$ & 3 & 3 & 1 & 0 \\
\hline Individual inventors & 0 & 1 & 0 & 0 \\
\hline Universities & 0 & 0 & 0 & 0 \\
\hline Government laboratories & 1 & 0 & 2 & 1 \\
\hline \multirow[t]{2}{*}{ Foreign sources } & 6 & 0 & 7 & 4 \\
\hline & 52 & 27 & 76 & 39 \\
\hline
\end{tabular}

SoURCE: A survey of inventions reported in the trade press and compiled by the author. A listing of these inventions, a brief description thereof, and the citations in the trade press can be obtained from the author.

a The breakdown here is Alcoa, 11; Kaiser, 10; Reynolds, 6; Harvey, 2; and Limited, 1.

other metals. Since 1940 some of these companies have supplied specialized welding equipment for use with aluminum.

The sources of inventions in joining from 1946 to 1957 are summarized in column 1 of Table 1 . The blanks and near-blanks drawn for secondary aluminum producers and independent fabricators were to be expected while the applied character of these inventions rules out the universities. The absence of any contribution by an individual inventor appears surprising in view of Jewkes' recent study which emphasized the contributions of individuals relative to those of corporate laboratories. ${ }^{14}$ Those who might be termed individual

14 John Jewkes, David Sawyers, and Richard Stillerman, The Sources of Invention, London, 1958, p. 82. 
inventors have sometimes joined one of the companies within the industry for the final stages in the development of their inventions. Furthermore, many of the equipment makers have small engineering organizations that provide the institutional environment of the individual inventor. Even so, independent inventors appear to be an unimportant source of invention.

The relatively low contribution of the primary producers and the relatively high contribution of the equipment makers is more striking. According to the preceding discussion, this would indicate that the competitive pressures and the more immediate, more certain, and larger relative increase in profits for the equipment makers offset larger potential long-run profits from inventions and the greater resources of the primary producers. The end-product manufacturers as a group are not an important source of invention despite their large numbers. Among the end-product manufacturers the aircraft companies predominate, which can be explained by the factors discussed previously.

Four joining inventions have been mentioned repeatedly in the trade press. Of these, the Koldweld process appears to be the most significant. The idea originated with a Royal Air Force officer, Sowter, who observed that when two sheets of copper were cut with dull shears a weld sometimes occurred on the sheared edge. This phenomenon was well known, but Sowter attempted to establish the conditions under which a weld would result. Upon demobilization, Sowter joined General Electric Ltd., a British welding equipment manufacturer. A research program conducted by the company developed the Koldweld process for aluminum. Even though the original idea was conceived by an individual inventor, it was within a large corporation that the invention was converted into a commercially feasible process. ${ }^{15}$

The Koldweld Corporation was organized to license the process in the United States. ${ }^{16}$ Under agreements with this corporation, the Utica Drop Forge and Tool Corporation developed and marketed a line of tools for the Koldweld process. ${ }^{17}$ This process, the first departure from conventional heat welding, is particularly important for those uses of aluminum in which the molecular structure of the metal must

${ }^{15}$ W. A. Barnes, "Connecting Aluminum Conductors by the Koldweld Process," Modern Metals, October 1955, p. 62. A Swiss aluminum fabricator is reported to have independently developed a similar process at about the same time.

16 "Fast Process Welds Aluminum Without Heating," ibid., December 1949, p. 28.

${ }^{17}$ Barnes, "Now Available: Tools for Koldwelding Wire and Sheet," ibid., April 1954, p. 57. Alcoa was reported as developing methods which extend the range of alloys that can be Koldwelded. 
be preserved. (Heat welding changes the physical characteristics of aluminum.) The use of Koldwelding is spreading, although it is by no means in general use.

At present, the most common method of welding aluminum is the heilarc process. Heilarc welding was developed by the Northrop Aviation Corporation in 1940 and is considered a "tremendous boon to the light metals industry." 18 In the postwar decade the Air Reduction Company, a welding equipment manufacturer, has made significant improvements in this process. ${ }^{19}$

The last two inventions accorded special mention are methods of brazing. Brazing joins metals through the flow of molten metal between joints without melting the metals to be joined and hence changing their physical properties. It is used primarily in air conditioning, automobile, and aircraft components where preserving the original heat transfer properties of aluminum is important. ${ }^{20}$ The Trane Company, a maker of aluminum components for aircraft and air conditioning, has developed a brazing process described as "the most significant heat transfer development in a quarter of a century." process developed jointly by United Aircraft Products and Alcoa is said, "to increase production rates, cut costs, and give a more efficient product design.",22

The origin of these apparently more major inventions corresponds roughly with the results obtained from the counting of the inventions, with one each coming from a British equipment maker, a domestic equipment maker, an end-product manufacturer, and one jointly from an end-product manufacturer and a primary producer.

\section{FINISHING}

Although aluminum does not rust, it is subject to corrosion and water staining. This has restricted the use of aluminum generally, although it is particularly crucial for aircraft components where aluminum gears, impeller blades, and so forth are subject to heat erosion and abrasion. ${ }^{23}$ Because the incidence of this technical problem is concentrated in the aircraft industry, it is a less valid test of the relative role

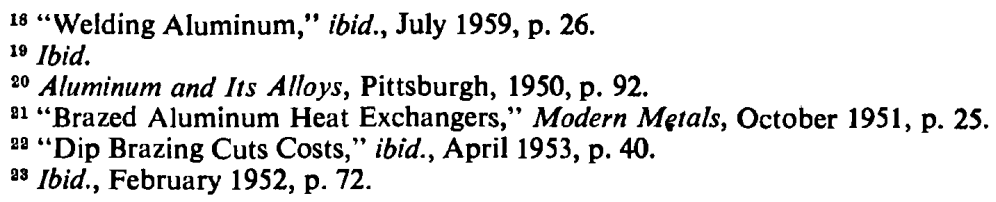


of different classes of inventors. Rather, the aircraft companies could be expected to be major sources of invention.

The computations in column 2 of Table 1 indicate that this is the case. Otherwise the results are similar to those for inventions in joining aluminum; namely, equipment makers are the major source of inventions and the primary producers are a relatively unimportant source. None of these inventions have been discussed extensively in the trade press.

\section{FABRICATING TECHNIQUES}

Fabricating converts aluminum ingot into sheet, rods, and bar castings for use by end-product manufacturers. The reporting of fabricating inventions in the trade press is incomplete for products such as aluminum sheet in which the primary producers account for over 90 per cent of the production, ${ }^{24}$ apparently because such inventions are of interest to only a few firms. (Independent fabricators do purchase reroll stock for finishing. Most of the rolling inventions listed below are for this type of rolling.) Consequently, the inventions in fabricating techniques reported here are largely limited to the fabricating carried on by both the independents and the primary producers. The primary producers account for about 40 per cent of the production fabricated by both independents and primary producers, with their share of individual products varying from 10 per cent in casting to 75 per cent in cable. ${ }^{25}$

The independent fabricators also vary greatly in size according to the product line. Extruding is largely a small business field containing firms with assets of as little as $\$ 200,000$. Cable wire, tubes, and shapes are produced by larger firms, though only a few, such as Revere Copper and Brass, are among Fortune's 500 largest industrial corporations. Some 3,000 foundries cast aluminum but most of these are specialty job shops. The mass production of die castings for the automobile industry is concentrated among a dozen or so comparatively large firms.

The primary producers realize gains from inventions in fabricating techniques through the increased demand for aluminum. For example, extrusion output expanded at about three times the rate of all fabricating output from 1950 to $1955,{ }^{26}$ in large part because the newer extrusion presses reduced the cost of this type of fabrication. Yet, as with

${ }^{24}$ See data in Small Business and the Aluminum Industry, p. 20.

25 Ibid.

26 Ibid. 
the inventions in manufacturing techniques, the gains of the primary producers are deferred and uncertain compared to those of the equipment makers. This is partially offset by the primary producers' direct gains through the utilization of fabricating techniques in their own operations. These gains are the more immediate reduction in costs rather than the longer-run profits from an increase in demand for aluminum.

The equipment makers occupy the same position with respect to the realization of profits as in the case of manufacturing techniques. The independent fabricators here are comparable to the end-product manufacturers in that they use the inventions directly in their own operations. The end-product manufacturers as the consumers of fabrications would profit from improvements in their supply.

As column 3 of Table 1 indicates, the equipment makers are the major source of fabricating inventions. Again, the more immediate and certain profits from invention for such firms appear to be the more effective stimulus for invention. Fabricating machinery, however, is often custom made for a specific fabricator with engineers from both the fabricator and the equipment maker working together on its design. Consequently, many inventions are the joint work of these two parties.

The three major inventions in fabricating technique originated abroad. Shell moulding, the most frequently discussed of the three inventions, utilizes a plastic shell as a mold rather than a more expensive metal die. Johannes Croning, a German engineer, invented the process in connection with wartime aircraft production. After the war Croning joined the Polygram Casting Co., Ltd., an English foundry, to further improve the process. ${ }^{27}$ Polygram holds the English patent and has applied for an American patent. As of 1953 the patent situation was described as "confused." 28

Three companies outside the aluminum industry were instrumental in the introduction of the Croning process in the United States. The Bakelite Division of Union Carbide and Chemical and Monsanto Chemical Company have promoted the process which requires the

${ }^{27}$ F. L. Church, "The Shell Molding Process," ibid., April 1952, pp. 28-33.

${ }^{28}$ Polygram claims, " . . it would be a serious mistake to assume that in its commercially practicable form [the Croning process] is open to free exploitation and that no Polygram license is necessary" (Modern Metals, March 1953, p. 30). Another group, Crown Casting Associates, has applied for an American patent. Modern Metals reports, "It has since been contended that the American patent claims are invalid and that an unlicensed foundry can without fear adopt the process in its own operations." (Church, "The Shell Molding Process," p. 28). 
plastics they manufacture. ${ }^{2 \theta}$ Shallenberger of the Stanford Business School and some of his former students have developed new machinery for shell casting. ${ }^{30}$ Over 100 foundries had adopted the process by $1953,{ }^{31}$ and its reception was such that one metallurgist cautioned, "The Croning process, though promising, is no panacea." 32

The Properzi continuous casting process was invented by an Italian engineer, again for wartime aircraft production. Properzi made further improvements after the war and the Nichols Wire and Aluminum Company, an American independent fabricator, introduced the process into the United States. Continuous casting permits a single machine to convert aluminum ingot directly into redrawn rod, thus eliminating several intermediate steps of the conventional production process. According to Properzi, "When contrasted to the multimillion dollar plants and large labor forces needed for conventional production of rod, it becomes obvious that continuous casting processes are revolutionary in their economic impact." ${ }_{33}$ To date, however, the economic impact has been limited, despite the considerable discussion of the Properzi process. Adoption has been discouraged by the initial cost of the machine $(\$ 175,000)$ and the radical changes required in existing operating techniques. There are now seven installations in the United States. ${ }^{34}$

The last major invention in fabricating technique is the large forging press. During the war, German aircraft firms built four extremely large presses that could form entire aircraft subassemblies, thus reducing the number of aircraft parts and so simplifying assembly and increasing structural strength. ${ }^{35}$ In 1948 the Air Force shipped two of these presses to the United States for installation in fabricating plants owned by Alcoa and Bridgeport Brass. (The Russians took the other two presses.) ${ }^{36}$ In 1950 the Air Force commissioned the building of even larger presses to be operated by Wyman Gorden, Alcoa, Kaiser, Harvey, and Curtiss Wright. ${ }^{37}$ These presses are

${ }^{29}$ Ibid., April 1952, p. 29.

${ }^{30}$ Ibid., August 1953, p. 26.

al Ibid., April 1953, p. 29.

${ }^{32}$ E. Eliot,. "Aluminum and Its Alloys in 1953-Some Aspects of Research and Technical Progress Reported," Metallurgia, February 1954, p. 82.

${ }^{33}$ Modern Metals, December 1953, p. 92.

34 Ibid., July 1953, p. 30.

35 "The aircraft designer has long been attracted to the idea of abandoning many of his substructures at present fabricated from sheer and extrusion and using forgings" (Elliot, op. cit., p. 82).

${ }^{36}$ Modern Metals, September 1956, p. 94.

37 Ibid., p. 96. 
considered a major engineering advance but their commercial value has yet to be established.

None of these inventions were introduced into the United States by the primary producers, which is consistent with the relatively limited role of these firms in the invention of fabricating techniques.

\section{END-PRODUCT APPLICATIONS}

The new product uses of aluminum since 1946 are too numerous for listing here ${ }^{38}$ Examples are such diverse products as (1) tubing for irrigation purposes, (2) shelving and refrigeration units for refrigerators, (3) lifeboats, davits, and ship superstructures, (4) mine props and beams, (5) low-tension electrical wire, (6) building products such as store fronts, lighting fixtures, window frames, and wall panels. Most of these inventions involved less of an advance in the state of the arts than those in the preceding sections, although some new applications called for the solution of difficult technical problems. The end-product manufacturers are the major source of these inventions. In view of their numbers and direct economic interest, any other result would be surprising. But the primary producers are also important contributors to this kind of technical change, both through assisting end-product manufacturers and through devising new endproducts.

Elsewhere the primary producers have been given low marks as sources of inventions. New end-products, however, promise a much more immediate payoff to a primary producer than the preceding types of inventions. Consider a shipyard deciding on the relative merits of steel and aluminum lifeboats. A primary producer assisting in the development of a new aluminum lifeboat can expect an immediate increase in its sales of aluminum. In contrast, a new method of welding or new fabricating techniques will increase the demand for aluminum only as these new processes become sufficiently widely diffused to increase the demand for aluminum. The concentration of the primary producers on end-product applications is reflected in the limited public descriptions of the sales and research organizations of the primary producers. ${ }^{39}$

\footnotetext{
${ }^{98}$ For a discussion of new applications, see the testimony of Mr. Wilson, president of Alcoa, in Remedy Record, pp. 953-970.

${ }^{39}$ See W. B. Griffin, "Kaiser Aluminum: More Metal for More Products for More People," Modern Metals, January 1956; E. A. Farrell, "Selling Aluminum," ibid., July and August 1956; and F. L. Church, "Man of the Year: David P. Reynolds," ibid., January 1955.
} 


\section{ALUMINUM ALLOYS}

The primary producers are likely to be the major source of new alloys (column 4 of Table 1), for the other types of firms do not have access to the technology and cannot realize direct and immediate gains from such inventions.

The primary producers have apparently concentrated their inventive efforts in alloys. ${ }^{40} \mathrm{New}$ alloys can be directly incorporated into the product line of the inventor so that the profits are relatively immediate compared to the profits from inventions in fabricating and manufacturing techniques. But perhaps more significantly, an alloy is more likely to increase the primary producer's share of the ingot market than other inventions. (Alloys are usually patentable whereas most new end-product applications are not.) Furthermore, a new alloy yields a profit for a primary producer even when it displaces an existing alloy so long as the inventor's market share increases. On the other hand, a new manufacturing or fabricating technique adds to a primary producer's profits only to the extent that it creates new uses for aluminum. Since the economic effect of an invention cannot be foreseen at the outset of the research, this two-fold possibility increases the certainty of a primary producer's profits from a new alloy.

But if immediacy and certainty characterize the profits from inventions in alloys, it does not follow that new alloys have been the most effective inventions in increasing the over-all demand for aluminum. New alloys account for only a small fraction of the total sales of aluminum ingot, indicating that these inventions have apparently played a minor role in the increase in aluminum demand. ${ }^{41}$ In contrast, the sale of extrusions, a product with significant changes in extruding techniques, has increased from a few per cent of the prewar total fabricating output in pounds to nearly 25 per cent of the 1958 output. $^{42}$

\section{Primary Producers and Equipment Makers as Sources of Invention}

Primary producers are an important source of inventions for new product applications and alloys, while they contributed relatively

${ }^{40}$ Data on the allocation of research expenditures were unavailable to the author. This statement is based upon qualitative descriptions of the research programs.

${ }^{41}$ In 1948 patented alloys accounted for 9 per cent of Alcoa's sales. This company at that time held the most alloy patents. Remedy Record, p. 1,729.

${ }^{42}$ See data in Small Business and the Aluminum Industry, p. 20. 
little toward advances in welding, finishing, and fabricating. Yet inventions in these last three categories have accounted for substantial increases in the demand for aluminum.

This is still consistent with the proposition that the primary producers direct their inventive efforts towards those sectors in which their profits are likely to be the highest, if profits are discounted for time and uncertainty. The significant finding is that the discounts required to explain the primary producers' behavior are of substantial magnitude and more than offset the greater resources of the large firms.

An alternative explanation is that the primary producers can count upon the inventions by others to exploit the technical opportunities in fabricating and manufacturing techniques. Therefore, the primary producers might concentrate their resources in the invention of the alloys where their activities might have a higher marginal value in increasing the demand for aluminum. Yet this view is inconsistent with the fact that the primary producers are active in the development of new end-product applications in which the end-product manufacturers are an effective alternative source of inventions. The critical difference appears to be the immediacy and certainty of the profits in the end-product applications.

In fabricating techniques, welding, and finishing, however, the rate of technical progress has been at least comparable with that in those sectors in which the primary producers are the major inventors. If a balance of payments between the small and the large business sectors were established for the flow of the benefits of technical progress, the primary producers might well be the debtor nation.

Within the small business group, the equipment makers are the major source of inventions. This is a pattern common to such diverse industries as textiles, coal mining, and railroading. Because the equipment makers in these industries are larger relative to their market than their customers are, it is sometimes argued that the differences in inventive activity are a result of differences in market power. In aluminum, however, the equipment makers are relatively small in their market compared to some of their customers and to all the primary producers. For the reasons set forth above, the nature of competition between the equipment makers as well as the nature of demand for their products suggests that equipment makers have a vested interest in technical change that transcends differences in market power. 


\section{Oligopoly, Monopoly, and Demand Increasing Inventions}

The second research question here is the relationship of oligopoly and monopoly to the rate of invention. Two new primary producers, Kaiser and Reynolds, were established in 1945 by the purchase of production plants constructed by the government during the war. ${ }^{43}$ Their entry ended Alcoa's prewar position as the sole domestic producer of primary aluminum.

Oligopoly is often considered more conducive to invention than monopoly simply because of the greater number of independent decisions and approaches. It is possible, of course, to have parallel approaches within a single research organization, but such a research strategy is discouraged by the cost of duplicative efforts and the difficulty of making truly independent decisions within a single hierarchical unit. Further, an oligopolist may sponsor more research activity for fear a rival may exploit the technical possibilities in order to increase his share. The simple case for monopoly is its ability to realize more fully the economies of scale in research, as well as the presumed higher rate of profit that may provide more funds for research.

A historical comparison between the years of one and several primary producers indicates that inventions have occurred at a higher rate in the postwar oligopoly. Some of the new applications represent the culmination of Alcoa's prewar technical pioneering. An industry nearly eight times its prewar size should be expected to have a larger absolute research effort and hence more inventions. Still, at least some part of this increased activity is assignable to the introduction of oligopoly. Notably, within a relatively short time Kaiser and Reynolds have generated inventions at about the same rate as Alcoa even though Alcoa is the largest firm of the three. In alloys, Alcoa has only one more invention to its credit than Kaiser and in new product applications, Reynolds appears to be the leader. This hardly suggests that if Alcoa were the only seller and so twice its present size, the total rate of inventions would be greater.

The second type of evidence concerns the effect of oligopoly upon marketing effort and, through that, the level of research. The existence

\footnotetext{
${ }^{43}$ There was no dissolution so that the problems of dividing a going research organization were avoided. However, during the war these plants were largely operated by Alcoa under management contracts.
} 
of several sellers apparently led to a greater pace in marketing effort, which in turn created pressures upon the research organization to develop new applications for aluminum and bring forth new alloys. It was through this marketing competition rather than direct research rivalry that oligopoly appears to have had an impact upon the rate of invention.

However, the primary producers' search for customers did not create a greater interest in new fabricating techniques. Rather, the effect of an oligopoly here was a more indirect one. The transition to oligopoly increased the significance of the independent fabricators ${ }^{44}$ and, with the increase in the number of independent fabricators, there was a corresponding increase in the number of equipment makers serving them. Granted that the sheer increase in size may account for some of the greater activity, an expansion in the role of the independent fabricator may have been necessary for an expansion in the research activities of the equipment makers.

\section{Oligopoly and Invention in Aluminum Ingot}

In the production of primary aluminum ingot the primary producers are the sole likely source of invention because there is no established "equipment" industry. This also holds true for the processing of alumina and the mining of bauxite, which are all vertically integrated operations of the primary producers.

The transportation of bauxite, a related process, provides an illustration of the value of independent and competing units in promoting technical change. ${ }^{45}$ After the war, there was discussion about the value of specialized ore vessels for the carriage of bauxite ore. At the remedy proceedings in 1949, Mr. Reynolds, president of Reynolds Metals, spoke highly of these specialized ore carriers. ${ }^{46} \mathrm{~A}$ few days later Mr. Wilson, president of Alcoa, testified,

We have made a continued and constant study as to the type of ships and type of service which will result in the lowest transportation costs and have figured ore carriers, which I heard Mr.

44 Accurate figures are hard to obtain. The number of independent fabricators increased from 12 to 168, excluding castings (Small Business and the Aluminum Industry, pp. 10 and 20). The competition between the primary producers resulted in a seeking out of the independent fabricators. Furthermore, a court order prohibited a repetition of the prewar "price squeeze" by the primary producers.

${ }^{45} \mathrm{I}$ am indebted to Alan Strout of the Harvard Economic Research Project for this example. The interpretation here is my own.

${ }^{46}$ Remedy Record, p. 188. 
Reynolds testify to ... we have examined the possibility of an ore carrier, one or more ore carriers - and to date we do not believe there will be any economy in utilizing an ore carrier. They are very expensive pieces of equipment and as such cannot be used for any other purpose than just hauling of ore. ${ }^{i 7}$

Shortly thereafter Reynolds commissioned an English firm to construct the S. S. Carl Schmedemen, the first self-loading bauxite carrier. The ship went into service and received "'good reviews" in Iron Age, The Engineer, and The Shipbuilding and Shipping Record. ${ }^{48}$ All those sources claimed a reduction in cost with such a ship, and one estimated the cost savings to be as much as one-third of the shipping costs with conventional equipment. Alcoa has since ordered two specialized ore carriers which may be more conclusive proof of their economic value. ${ }^{49}$

The ore carrier is typical of the technical changes since the warfairly prosaic and originating in the general advances in technology. Alan Strout, of the Harvard Economic Research Project, describes the technical changes in aluminum reduction "as a procession of nonrevolutionary though significant factor saving innovations." ${ }_{50} \mathrm{He}$ lists changes in location of production facilities, use of new fuel sources, increases in the size of reduction pots, greater amperage, introduction of a continuous process for alumina digestion and electrode formation, improvement in electrical generation and transmission, mechanization of material handling, and improvement in the electronic control system.

The prewar pattern of technical change is quite similar, except that there were several more major inventions to enliven the record. ${ }^{51}$ The best known is the Soderberg process which utilizes an anode self-

47 Ibid., p. 726.

${ }^{48}$ Shipbuilding and Shipping Record, December 4, 1952; The Engineer, January 16, 1953, p. 98; and Iron Age, December 4, 1952, p. 209.

${ }^{49}$ Shipbuilding and Shipping Record, May 12 1955, p. 606. Such specialized ore carriers are now used in hauling other ores and are ranked "As one of the most important changes which has marked shipbuilding in recent years" (Merchants Ships, 1954, New York, 1955 , p. 64). Even without Reynold's leadership, Alcoa would probably have adopted this general shipping practice eventually.

${ }^{50}$ Alan M. Strout, "The Aluminum Industry," in Harvard Economic Research Project, Report on Research for 1956-57, Cambridge 1957, hectographed, p. 71.1 am indebted to Strout for several sources cited in the following pages.

${ }^{51}$ Donald Wallace, writing in 1937, states, "With a few exceptions, which will be noted in due course, no fundamental alterations of process or apparatus have occurred since the birth of the industry." (Market Control, p. 7). Similarly, speaking about the Bayer process since 1928, Mr. Wilson, president of Alcoa, testified, "[the Bayer process] has had only such changes as result in material handling and general processing equipment." (Remedy Record, p. 975). 
baked in the reduction pot and continuously restored by additions of a carbon mixture. This process is considerably cheaper than using a pre-baked anode. ${ }^{52}$ The continuous digestion, the lime and soda, and the starch processes were significant modifications of the Bayer process for converting bauxite into alumina. The Soderberg process was invented by a Norwegian producer and the Bayer process modifications by Alcoa.

Aluminum is still produced by the Hall process discovered in 1887 , and alumina by the Bayer process discovered in 1920. There have been rumors of revolutionary discoveries in the offing. For example, Reynolds has patented a process to extract aluminum directly from bauxite, thus by-passing the production of alumina. ${ }^{53}$ The British Columbia Aluminum Company has announced the reduction of aluminum by long-wave electrical energy. ${ }^{54}$ The Bureau of Mines, Alcoa, Harvey, and Anaconda have large research programs directed at the production of alumina from domestic clays. ${ }^{55}$ Yet, except for brief press announcements of "promising" results, this research has been to no apparent avail, and the Hall and Bayer processes are likely to be used for years to come.

Continuous minor improvements have made these two processes highly efficient. For example, the Bayer process recovered on the average 95 per cent of the alumina in the bauxite ores even before the war and today the recovery percentage is 97 per cent. ${ }^{56}$ Similarly, the electrical input per pound of aluminum was 12 kilowatt hours in 1926, 10 kilowatt hours in 1940, and 7.8 kilowatt hours in a plant constructed in 1954. ${ }^{57}$ At the same time, the Hall and Bayer processes appear to have exploited fully the electrochemical knowledge that accumulated at the turn of the century. Processes that have had continuous minor improvements and were initially major advances in the state of the art are difficult to surpass.

${ }^{52}$ Department of Commerce, Business and Defense Service Administration, Materials Survey: Aluminum, November 1956, pp. VI 8-10.

${ }^{53}$ Modern Metals, September 1948, p. 48.

${ }^{54}$ Ibid., March 1952, p. 18.

${ }^{55}$ For a history of the early efforts see John V. Krutilla, "The Structure of Costs and Regional Advantage in Primary Aluminum" (dissertation submitted to Harvard University, 1952) and for more recent discussion see Modern Metals, October 1953, p. 28; May 1953, p. 88; and December 1955, p. 92.

${ }^{56}$ T. G. Pearson, "The Chemical Background of the Aluminum Industry," Royal Institute of Chemistry, Lectures, Monographs and Reports, No. 5, London, 1956, p. 34.

${ }^{57}$ The last figure is for the Anaconda plant, built in 1954. Edwin O. Wooster, "A Description of the Anaconda Aluminum Plant at Columbia Falls, Montana," an address at the Colorado Mining Association, February 7, 1956. 
What is required is another major increase in scientific knowledge comparable to that which made possible the Hall invention. Donald Wallace traces the Hall invention back to "scientific research and formulation of general principles governing the relations of electric currents to chemical changes . . ." "58 Such advances in scientific knowledge are the culmination of a series of scientific discoveries and are relatively rare events. For this kind of technical change, economics, at least the kind involved in the study of markets, is irrelevant.

\section{Concluding Comment}

The conclusions, as stated in each section, are not particularly novel. Most economists would agree that oligopoly is more conducive to invention than monopoly. The evidence here supports this proposition, although at the reduction stage the changes in market structure made no observable difference in the rate and nature of invention. The finding that even large firms focus their inventive activities in areas where the profits are relatively immediate and certain is not surprising, although there are few statements as to the limits of inventive activity of a firm, largely because few have posed the question.

The role of the equipment makers demonstrates that a substantial part of the technical change in one industry is likely to stem from progress of another industry. The importance of growth industries for particular historical periods, such as the automobile and rayon for the 1920 's, is a common theme in economic history. There may well be industries that are less obviously major carriers of technical change, not only for a single historical period but more or less continuously, by virtue of their position in the economy. To generalize here, however, requires more knowledge than now exists of interindustry flows of technical change.

${ }^{68}$ Wallace, Market Control, p. 4. 